\title{
The Serological Properties of the Cell Surface Proteins of Vibrio cholerae
}

\author{
By SHAHJAHAN KABIR† \\ The National Bacteriological Laboratory, Stockholm, Sweden and the International Centre for \\ Diarrhoeal Disease Research, Dacca, Bangladesh
}

(Received 18 November 1982; revised 26 January 1983)

\begin{abstract}
The serological properties of cell surface proteins of Vibrio cholerae belonging to both the biotypes (classical and El Tor) and the serotypes (Ogawa and Inaba) were investigated. Proteins were isolated by extracting $V$. cholerae with EDTA in the presence of sodium chloride. The surface localization of these proteins was confirmed with (a) radioiodinated protein $A$ as an immunoprobe and (b) antiserum absorption studies with whole bacteria. There were similarities among the polypeptides of cell surface proteins isolated from various $V$. cholerae types. Antisera to these proteins agglutinated several $V$. cholerae strains, irrespective of biotype, serotype and antibiotic sensitivity. The antisera did not agglutinate pathogenic enteric bacteria such as enterotoxigenic Escherichia coli, Salmonella typhi, Shigella spp., Aeromonas hydrophila and Yersinia enterocolitica. The cell surface proteins of $V$. cholerae were immunogenic in rabbits as high titres of anti-protein specific antibodies were detected by the ELISA technique in the immune sera. These results suggest that the cell surface proteins are common antigens of $V$. cholerae and can be developed as a potential vaccine candidate against cholera.
\end{abstract}

\section{INTRODUCTION}

Vibrio cholerae is a Gram-negative bacterium which colonizes the small intestine. There it secretes a protein toxin which binds to the mucosal epithelial cells and stimulates adenylate cyclase activity in the intestinal tract. The process alters ion transport at the mucosal surface and finally causes diarrhoea (Field, 1971). Clinical cholera induces both antitoxic and antibacterial immunities in the infected host (Majumdar et al., 1981). Although cholera is a toxin-mediated disease, recent volunteer studies have demonstrated that antibacterial immunity was more important in protecting human beings than antitoxic immunity (Levine et al., 1979).

The surface of $V$. cholerae, like other Gram-negative bacteria, consists of macromolecules including proteins and LPS (Kabir \& Mann, 1980; Kabir, 1980). Among the various cell surface components of $V$. cholerae examined, proteins have been found to be lacking toxic properties (Kabir \& Mann, 1980). Diarrhoea in man may be caused by several enteric bacteria such as $V$. cholerae (both $\mathrm{O} 1$ and non-O1 strains), $V$. parahaemolyticus, enterotoxigenic Escherichia coli, Aeromonas hydrophila, Shigella spp. and Yersinia enterocolitica (Craig, 1980). Whether $V$. cholerae shares cross-reacting surface protein antigens with other members of enteric bacteria causing diarrhoeal illness has not been investigated. Also, little is known about the immunogenicity of cell surface proteins of $V$. cholerae.

The present investigation was initiated (i) to study the serological properties of surface proteins of $V$. cholerae belonging to both biotypes (classical and $\mathrm{El}$ Tor) and both serotypes (Ogawa and Inaba), (ii) to investigate the antigenic cross-reactivity of cell surface proteins of $V$. cholerae to other members of enteric bacteria causing diarrhoeal illness, and (iii) to determine the immune response to cell surface proteins of $V$. cholerae in animals such as rabbits.

† Address for correspondence: Tobaksspinnargatan 5, 11736 Stockholm, Sweden. 


\section{METHODS}

Bacterial strains. The majority of cultures were obtained from the collection of the International Centre for Diarrhoeal Disease Research, Bangladesh (Table 1). A total of 117 cultures of Vibrio cholerae O1, isolated mostly from patients suffering from cholera epidemics in Bangladesh, were used. Of these, 43 isolates were resistant to antibiotics ampicillin, kanamycin, tetracycline, streptomycin and trimethoprim-sulphamethoxazole. Nineteen enterotoxigenic Escherichia coli strains isolated from diarrhoeal stools were studied. Of these, six produced only the heat-labile toxin (LT), seven only the heat-stable toxin (ST) and the remaining six produced both toxins. Twelve strains of $V$. cholerae non-Ol and six strains of Vibrio parahaemolyticus were also included in the study. Sixteen cultures of Shigelli: spp., belonging to major serotypes (Sh. dysenteriae, Sh. flexneri, Sh. boydii and Sh. sonnei) were investigated. Also included in the study were ten cultures of Salmonella typhi, three cultures of Aeromonas hydrophila and two cultures of Yersinia enterocolitica.

Growth conditions. Vibrio cholerae cultures were grown both on solid and in liquid media. Vibrio cholerae cultures were plated on to solid nutrient agar $(1 \%, w / v$, Difco $)$ and incubated at $37^{\circ} \mathrm{C}$ overnight. For mass cultivation, a $3 \%$ $(\mathrm{w} / \mathrm{v})$ solution of peptone-water was used as the liquid growth medium. Bacteria were grown with continuous shaking at $37^{\circ} \mathrm{C}$ and were harvested at the stationary phase of the growth $(12 \mathrm{~h})$. Vibrio parahaemolyticus was cultivated in the peptone-water containing $3 \%(\mathrm{w} / \mathrm{v}) \mathrm{NaCl}$.

Cultures of Shigella spp., enterotoxigenic E. coli, S. typhi, A. hydrophila and Y. enterocolitica were grown on blood agar plates at $37^{\circ} \mathrm{C}$.

Extraction of cell surface proteins of Vibrio cholerae. A $10 \mathrm{~g}$ (wet weight) sample of $V$. cholerae 395 (Ogawa) was washed twice with cold $\left(4^{\circ} \mathrm{C}\right) 0.1 \mathrm{M}-\mathrm{NaCl}$ and subsequently with cold EDTA/ $\mathrm{NaCl}(25 \mathrm{ml}, 0.12 \mathrm{M}$-EDTA $/ 0.77 \mathrm{M}$ $\mathrm{NaCl}, \mathrm{pH} 7 \cdot 2)$. The combined extracts were centrifuged $(20000 \mathrm{~g}, 30 \mathrm{~min})$ and concentrated by negative pressure dialysis. EDTA was removed by dialysis against $0.01 \mathrm{~m}$-phosphate buffered saline (PBS), pH 7-2. The dialysate was centrifuged at $10000 \mathrm{~g}$ for $15 \mathrm{~min}$ and the resulting supernate was used for further investigation.

Isolation of LPS. The LPS from $\boldsymbol{V}$. cholerae 395 (Ogawa) was prepared by the phenol/water procedure as described by Westphal et al. (1952). The crude LPS was further purified to remove proteins and nucleic acids by procedures involving repeated ultracentrifugation at $105000 \mathrm{~g}$ (Westphal \& Jann, 1965). Protein content was determined by the Lowry method, using bovine serum albumin as the standard.

$P A G E$. PAGE in the presence of SDS was performed according to the procedure of King \& Laemmli (1971). Briefly, the gel $(10 \%$, w/v, acrylamide) was cast between glass plates $(15 \times 15 \mathrm{~cm})$ to a height of $10 \mathrm{~cm}$, using spacers $1.5 \mathrm{~cm}$ thick. A stacking gel ( $3 \%$, w/v, acrylamide) $2 \mathrm{~cm}$ high was applied on top of the analytical gel. Electrophoresis was performed at $30 \mathrm{~mA}$ until the tracking dye reached the end of the analytical gel. Bovine serum albumin $(68 \mathrm{kDal})$, ovalbumin $(45 \mathrm{kDal})$ and cytochrome $c(11.7 \mathrm{kDal})$ were used as marker proteins.

Preparation of antisera. Antisera against whole cells were raised in rabbits by injecting $10^{9} \mathrm{~V}$. cholerae suspended in Freund's complete adjuvant (Difco) intramuscularly on days $0,14,28$ and 42. Blood was collected 1 week after the last immunization.

Antisera against cell surface proteins were prepared with injection mixtures containing $1 \mathrm{mg}$ protein in Freund's complete adjuvant. Rabbits were immunized as described above. Antisera were stored at $-70{ }^{\circ} \mathrm{C}$ until use.

Absorption of serum with LPS. To remove immunoglobulins against the Ogawa LPS, the antisera $(1 \mathrm{ml})$ was treated with the LPS $(5 \mathrm{mg})$ from $V$. cholerae 395 (Ogawa) overnight at $4{ }^{\circ} \mathrm{C}$. The LPS absorbed antisera was centrifuged at $105000 \mathrm{~g}$ for $4 \mathrm{~h}$. The supernate was stored at $-18^{\circ} \mathrm{C}$.

Localization of surface proteins of $V$. cholerae by a radioimmunochemical technique. (a) Radioiodination of protein $A$. (The protein was kindly prepared by Ms G. H. Vos-Scheperkeuter.) Protein A (Pharmacia) was labelled with ${ }^{125}$ I by the chloramine $\mathrm{T}$ method (Hunter \& Greenwood, 1962). Briefly, to $100 \mu \mathrm{g}$ protein A (10 mg ml phosphate buffer, $\mathrm{pH} 7.5) 50 \mu \mathrm{g}$ chloramine $\mathrm{T}\left(5 \mathrm{mg} \mathrm{ml}^{-1}\right.$ in phosphate buffer) and $0.5 \mathrm{mCi}(18.5 \mathrm{MBq})$ carrierfree $\mathrm{Na}^{125}$ I (Amersham) were added. The mixture was incubated for $3 \mathrm{~min}$ at room temperature, the reaction was stopped by adding $200 \mu \mathrm{g}$ sodium metabisulphite $\left(10 \mathrm{mg} \mathrm{Na} \mathrm{S}_{2} \mathrm{O}_{5} \mathrm{ml}^{-1}\right.$ in phosphate buffered saline) and the sample was diluted with $400 \mu \mathrm{l}$ PBS containing $1 \mathrm{mg}$ bovine serum albumin $\mathrm{ml}^{-1}$. The radioiodinated protein $\mathrm{A}$ was separated from ${ }^{125}$ I by chromatography on a SephadexG-50 column. Protein A, labelled to a specific activity of $2 \mu \mathrm{Ci} \mu \mathrm{g}^{-1}$, was eluted in the void volume.

(b) Immunoassay with ${ }^{125}$ I-labelled protein $A$. The antisera to surface proteins of $V$. cholerae 395 was absorbed with LPS, as described above. The absorbed sera had an IgG concentration of $15 \mathrm{mg} \mathrm{ml}^{-1}$ as determined spectrophotometrically at $280 \mathrm{~nm}$ by the procedure of Crumpton \& Wilkinson (1963).

Cell suspensions of $V$. cholerae $395\left(2 \times 10^{8}, 100 \mu \mathrm{l}\right)$ were taken up in Eppendorf tubes and were incubated with increasing amounts of antisera (10-100 $\mu$ l) at room temperature for $30 \mathrm{~min}$. Cells were washed three times with phosphate-buffered saline and resuspended in a total volume of $200 \mu \mathrm{l}$ PBS. To prevent non-specific clumping of cells, a drop of $5 \%(\mathrm{w} / \mathrm{v})$ bactotryptone (Difco) was added to the cell suspension. To determine cell-bound antigenantibody complexes, $100 \mu \mathrm{l}^{125} \mathrm{I}$-protein $\mathrm{A}\left(2.27 \times 10^{6} \mathrm{~d}\right.$.p.m. $)$ was added to the cell suspension. After incubation for $1 \mathrm{~h}$, cells were centrifuged at $10000 \mathrm{~g}$ and the pellet was washed as described above. To check the specificity of 
Table 1. Bacterial strains used in the study

\begin{tabular}{|c|c|c|c|c|}
\hline Organism & $\begin{array}{l}\text { No. of } \\
\text { strains }\end{array}$ & Strain designation & Characteristics* & Source $\dagger$ \\
\hline \multirow[t]{2}{*}{ Vibrio cholerae $\mathrm{O} 1$} & 61 & $\begin{array}{l}\text { W-13021, W-28310, W-28422, W-28431, } \\
\text { W-28432, W-28433, W-28437, W-28549, } \\
\text { W-28586, W-28593, W-28595, W-28613, } \\
\text { W-28616, W-28619, W-28620, X-32, } \\
\text { X-76, X-95 }\end{array}$ & Ogawa, El Tor & ICDDR,B \\
\hline & & $\begin{array}{l}\text { U-700, U-1164, U-1194, U-1881, } \\
\text { U-2127, U-2128, U-2352, U-2355, } \\
\text { U-2371, U-2374, U-2568, U-2983, } \\
\text { U-2986, U-14361, U-14490, U-14553, } \\
\text { U-14690, U-14754, U-14805, U-17411, } \\
\text { U-14898, W-15285, W-15746, W-16242, } \\
\text { W-16243, W-16245, W-16355, W-16356, } \\
\text { W-16358, W-16359, W-18230, W-18271, } \\
\text { W-18450, W-18465, W-18468, W-18493, } \\
\text { W-18509, W-18522, W-18556, W-18589, } \\
\text { W-18591, T-20464, U-14365 }\end{array}$ & $\begin{array}{l}\text { Ogawa, El Tor } \\
\text { (resistant to antibiotics } \\
\text { ampicillin, tetracycline, } \\
\text { streptomycin, kanamycin, } \\
\text { and trimethoprim- } \\
\text { sulphamethoxazole) }\end{array}$ & ICDDR,B \\
\hline Vibrio cholerae $\mathrm{O} 1$ & 46 & $\begin{array}{l}\text { W-28419, W-28427, W-28428, W-28430, } \\
\text { W-28438, W-28442, W-28449, W-28451, } \\
\text { W-28453, W-28466, W-28590, W-28591, } \\
\text { W-28592, W-28594, W-28596, W-28597, } \\
\text { W-28598, W-28599, W-28600, W-28624, } \\
\text { X-17, X-18, X-19, X-22, X-23, X-36, } \\
\text { X-69, X-116, X-122, X-123, X-131, X-180, } \\
\text { X-232, X-235, X-370, X-376, X-378, } \\
\text { X-453, X-454, X-501, X-503, X-504, } \\
\text { X-508, X-513, X-540, T-19479 }\end{array}$ & Inaba, El Tor & ICDDR,B \\
\hline Vibrio cholerae $\mathrm{O} 1$ & 5 & $\begin{array}{l}395 \\
\text { T-19765, T-19766, T-19767, T-19768 }\end{array}$ & Ogawa, classical & $\begin{array}{l}\text { India }{ }^{\mathrm{a}} \\
\text { ICDDR,B }\end{array}$ \\
\hline Vibrio cholerae $\mathrm{O} 1$ & 5 & $\begin{array}{l}\text { 569B } \\
\text { H-22861, H-23448, H-23055, } \\
10732\end{array}$ & Inaba, classical & $\begin{array}{l}\text { India }^{b} \\
\text { ICDDR,B } \\
\text { NCTC }\end{array}$ \\
\hline Vibrio cholerae non-O1 & 12 & $\begin{array}{l}\text { U-3902, U-4026, U-4551, U-8281, } \\
\text { U-10119, U-12028, U-12031, U-21051, } \\
\text { W-2484, W-4556, W-5963, W-12379 }\end{array}$ & & ICDDR,B \\
\hline $\begin{array}{l}\text { Vibrio } \\
\text { parahaemolyticus }\end{array}$ & 6 & $\begin{array}{l}\text { U-24576, U-25077, U-25301, } \\
\text { W-2365, W-4847, W-9078 }\end{array}$ & & ICDDR,B \\
\hline \multirow[t]{3}{*}{ Enterotoxigenic $E$. coli } & 6 & $\begin{array}{l}\text { W-29665, W-29891, W-30750, } \\
\text { W-31453, Tc-218425, Tc-225725 }\end{array}$ & $\mathrm{LT}^{+}$ & \\
\hline & 6 & $\begin{array}{l}\text { W-29350, W-29663, W-29668, } \\
\text { W-30185, W-31286, Tc-201925 }\end{array}$ & $\mathrm{LT}^{+}, \mathrm{ST}^{+}$ & \\
\hline & 7 & $\begin{array}{l}\text { W-28266, W-28738, W-29987, W-30422, } \\
\text { W-30746, Tc-228575, Tc-216500 }\end{array}$ & $\mathrm{ST}^{+}$ & \\
\hline Salmonella typhi & 10 & $\begin{array}{l}\text { U-11293, U-11628, U-11793, W-4531, } \\
\text { W-4750, W-5037, W-5118, W-5890, } \\
\text { W-5982, W-6040 }\end{array}$ & & ICDDR,B \\
\hline Aeromonas hydrophila & 3 & N-4730, N-19802, N-20701 & & ICDDR,B \\
\hline $\begin{array}{l}\text { Yersinia enterocolitica } \\
\text { Shigella }\end{array}$ & 2 & A, B & & ICDDR,B \\
\hline Sh. sonnei & 3 & $\mathrm{~W}-13041, \mathrm{~W}-13402, \mathrm{~W}-14113$ & & ICDDR,B \\
\hline Sh. boydi & 3 & U-2187, W-3121, W-12394 & & ICDDR,B \\
\hline $\begin{array}{l}\text { Sh. dysenteriae } \\
\text { Sh flexneri }\end{array}$ & 3 & $\mathrm{U}-2127, \mathrm{~W}-13114, \mathrm{~W}-13114$ & & $\begin{array}{l}\text { ICDDR,B } \\
\text { ICDDR,B }\end{array}$ \\
\hline Sh. flexnerl & 1 & $\begin{array}{l}\text { W-1332, W-12870, W-13132, W-13211 } \\
\text { W-13295, W-15920, W-19332 }\end{array}$ & & ICDDK, $\mathrm{B}$ \\
\hline
\end{tabular}

* LT, heat labile toxin: ST, heat stable toxin.

$\dagger$ ICDDR, B, International Centre for Diarrhoeal Disease Research, Bangladesh; NCTC, The National Collec-

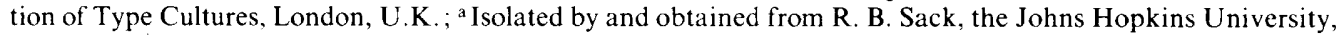

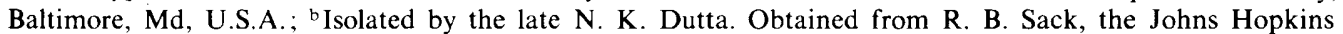
University, Baltimore, Md, U.S.A. 
the reaction cells of $V$. cholerae 395 were incubated with the preimmune serum and ${ }^{125}$ I-protein $A$. The cell pellet was suspended in a total volume of $200 \mu \mathrm{l}$ PBS. the cell-bound radioactivity was determined by counting samples in a gamma counter with tetrabutylin-loaded scintillator (Gammavial C, Koch-Light).

ELISA. Cell surface proteins were suspended in $0 \cdot 1 \mathrm{M}-\mathrm{NaHCO}_{3}(\mathrm{pH} 9 \cdot 6)$ at the optimal concentration of $50 \mu \mathrm{g}$ protein $\mathrm{ml}^{-1}$. Individual wells of ELISA plates (Cooke Laboratory Products, Alexandria, Va., U.S.A.) were coated with the protein suspension $(100 \mu \mathrm{l})$ at room temperature for $16 \mathrm{~h}$. The antigen was discarded and the wells were washed three times with phosphate-buffered saline, pH 7.4 containing $0.05 \%$ (v/v) Tween 20 (PBST). Rabbit antisera to $V$. cholerae 395 (Ogawa) cells were preabsorbed with Ogawa LPS. Ten-fold dilutions of the test sera in PBST were added in $100 \mu$ portions to the antigen-coated wells and incubated at room temperature for $1 \mathrm{~h}$. Control wells without the antigen were also filled with antiserum. The wells were emptied and washed three times with PBST. The wells were filled with $100 \mu \mathrm{l}$ of a sheep anti-rabbit immunoglobulin-alkaline phosphatase conjugate (specific for rabbit immunoglobulins G, M and A) and left at room temperature for $18 \mathrm{~h}$. After washing three times with PBST, $100 \mu \mathrm{l}$ of the enzyme substrate ( $p$-nitrophenylphosphate, Sigma, $2 \mathrm{mg} \mathrm{ml}^{-1}$ in water) was added and the plates were incubated at $22^{\circ} \mathrm{C}$ for $60 \mathrm{~min}$. The reaction was terminated by the addition of $0 \cdot 1 \mathrm{M}$ $\mathrm{NaOH}$ and the samples were read in an ELISA colorimeter at $400 \mathrm{~nm}$.

Bacterial agglutination. Bacterial cultures were adjusted to $10^{10}$ cells $\mathrm{ml}^{-1}$ in $0.2 \mathrm{M}$-phosphate-buffered saline ( $\mathrm{pH} 7 \cdot 2$ ). Twofold dilutions of antisera to surface protein antigens from $V$. cholerae 395 (Ogawa) were added to an equal volume of bacteria in microtitre plates. Prior to addition, the antisera were incubated in a water bath at $56^{\circ} \mathrm{C}$ for $30 \mathrm{~min}$. The agglutination pattern was recorded after incubation for $2 \mathrm{~h}$ at room temperature.

\section{RESULTS}

\section{Composition of the EDTA extracted material of $V$. cholerae}

The extraction of $V$. cholerae by EDTA in the presence of sodium chloride was monitored by electron microscopy; no cell lysis was observed. The polar flagellum of $V$. cholerae also remained intact. Chemical analysis of the extracted material showed it to be predominantly protein $(90 \%)$.

The EDTA extracts from four strains of $V$. cholerae belonging to both biotypes (classical and El Tor) and serotypes (Ogawa and Inaba) were analysed by PAGE in the presence of SDS (Fig. 1). The extracts from each strain were resolved into several polypeptides. There were similarities in the polypeptide composition as these preparations all contained a major band of approximate molecular weight 48000 . In addition polypeptides of approximate molecular weights 66000 , 28000 and 13000 were present in all the strains examined. Variations were observed in a few minor bands among these strains.

\section{Surface localization of the EDTA extracted proteins}

Bacterial agglutination technique. To determine the localization of the EDTA extracted proteins, agglutination tests were done. Antisera, raised to the EDTA extracted material from $V$. cholerae 395 (classical, Ogawa) in rabbits, were absorbed with freshly grown $V$. cholerae 395 cells and were subsequently tested for bacterial agglutinating activity. While the unabsorbed antisera agglutinated whole $V$. cholerae 395 cells, the absorbed sera failed to do so.

Radioimmunochemical technique. Protein A obtained from Staphylococcus aureus binds to the $\mathrm{F}_{\mathrm{c}}$ part of IgG molecules (Sjoquist et al., 1972). Hence, ${ }^{125} \mathrm{I}$-protein A has been used to detect cell surface antigens (Langone et al., 1977). The anti-LPS activity of the antisera, raised to the EDTA extracted material from $V$. cholerae 395 (Ogawa), was removed by absorption with LPS of the same serotype. Cells of $V$. cholerae 395 were incubated with the absorbed antisera and later treated with ${ }^{125} \mathrm{I}$-protein A. When $2 \times 10^{8} \mathrm{~V}$. cholerae 395 (Ogawa) cells were incubated with $0.75 \mathrm{mg}$ surface protein specific $\mathrm{IgG}$, the binding of ${ }^{125} \mathrm{I}$-protein A reached a plateau, signifying saturation of exposed proteins. The uptake of ${ }^{125}$ I-protein A by $V$. cholerae was specific as very little radioactivity was bound when cells were incubated with the preimmune serum.

\section{ELISA}

To determine the antigenicity of the cell surface proteins of $V$. cholerae, ELISA tests were done with the surface proteins as the coating antigen. Rabbits were immunized with $V$. cholerae 395 and the immune sera were absorbed with LPS. As shown in Fig. 2, high titres of the cell 


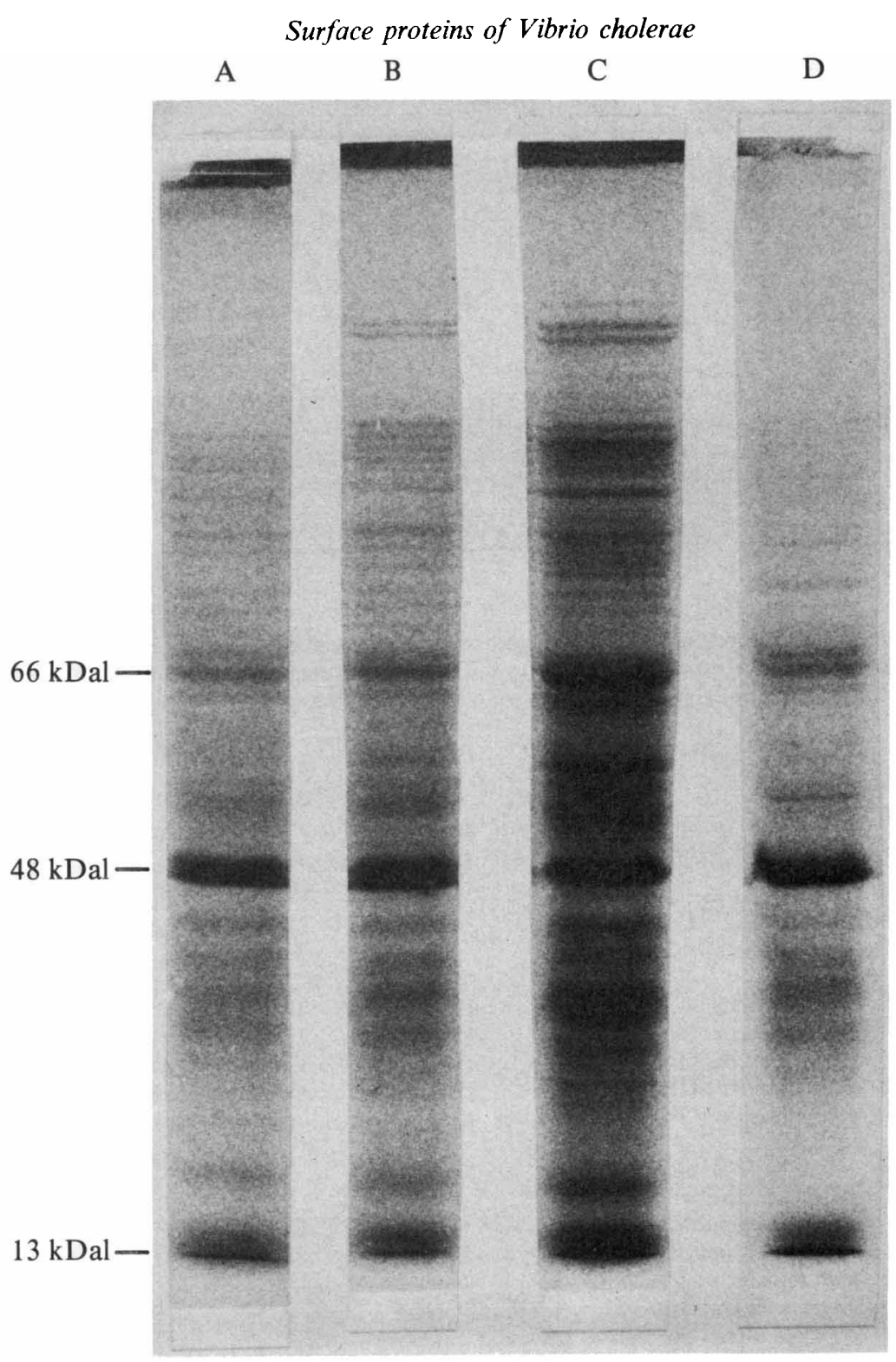

Fig. 1. SDS-PAGE of surface proteins of $V$. cholerae from the following strains (A) W-13021 (El Tor, Ogawa); (B) 395 (classical, Ogawa); (C) 569B (classical, Inaba) and (D) T 19479 (El Tor, Inaba).

surface protein specific antibodies were detected in the sera suggesting that these proteins were immunogenic.

\section{Agglutination studies}

Antisera to the surface proteins from $V$. cholerae 395 were tested against 117 strains of $V$. cholerae $\mathrm{O} 1$; the antisera agglutinated all these strains (Table 2). Of these, 43 strains showed multiple resistance to the antibiotics ampicillin, streptomycin, kanamycin, tetracycline and trimethoprim-sulphamethoxazole. These results suggest that the surface proteins represent the common antigens of $V$. cholerae.

To determine whether the surface proteins of $V$. cholerae bear serological relationship with other diarrhoea-causing members of the genus Vibrio, agglutination studies were done with 12 


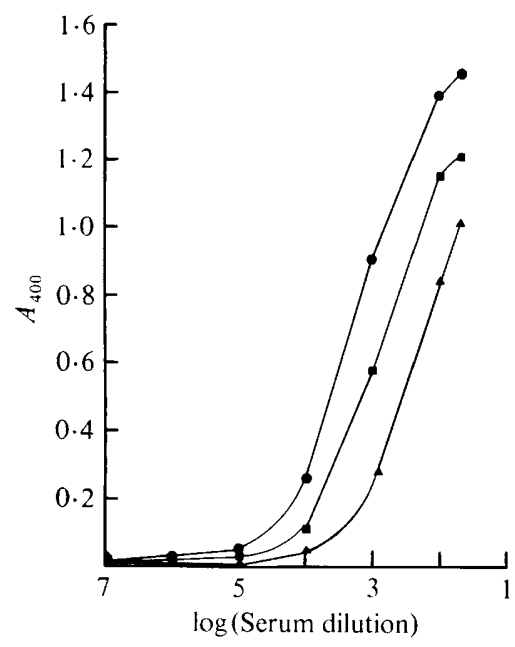

Fig. 2. Detection of anti-cell surface protein antibodies by the microtitre ELISA technique. The assay was carried out as described in the text, using cell surface proteins from $V$. cholerae 395 (classical, Ogawa) as the coating antigen. The antisera were raised in three rabbits.

Table 2. Agglutination of various diarrhoeagenic bacteria by antisera to cell surface proteins from Vibrio cholerae 395 (classical, Ogawa)

\begin{tabular}{|c|c|c|}
\hline $\begin{array}{l}\text { Agglutination } \\
\text { reaction }\end{array}$ & $\begin{array}{l}\text { No. of strains } \\
\text { studied }\end{array}$ & Characteristic* \\
\hline \multicolumn{3}{|l|}{ Positive: } \\
\hline Vibrio cholerae $\mathrm{Ol}$ & 61 & El Tor, Ogawa \\
\hline Vibrio cholerae $\mathrm{Ol}$ & 46 & El Tor, Inaba \\
\hline Vibrio cholerae $\mathrm{O1}$ & 5 & Classical, Ogawa \\
\hline Vibrio cholerae $\mathrm{O} 1$ & 5 & Classical, Inaba \\
\hline Vibrio cholerae $\mathrm{O} 1$ & 43 & Antibiotic resistant \\
\hline \multicolumn{3}{|l|}{ Negative: } \\
\hline Vibrio cholerae non-O1 & 12 & \\
\hline Vibrio parahaemolyticus & 6 & \\
\hline Enterotoxigenic $E$. coli & 6 & $\mathrm{LT}^{+}$ \\
\hline Enterotoxigenic $E$. coli & 7 & $\mathrm{ST}^{+}$ \\
\hline Enterotoxigenic $E$. coli & 6 & $\mathrm{LT}^{+}, \mathrm{ST}^{+}$ \\
\hline Salmonella typhi & 10 & \\
\hline \multicolumn{3}{|l|}{ Shigella } \\
\hline Sh. dysenteriae & 3 & \\
\hline Sh. flexneri & 7 & \\
\hline Sh. boydi & 3 & \\
\hline Sh. sonnei & 3 & \\
\hline Aeromonas hydrophila & 3 & \\
\hline Yersinia enterocolitica & 2 & \\
\hline
\end{tabular}

* Antibiotic resistant denotes resistance to tetracycline, ampicillin, kanamycin, streptomycin and trimethoprim-sulphamethoxazole; LT, heat labile toxin, ST, heat stable toxin.

strains of $V$. cholerae non-Ol and six strains of $V$.parahaemolyticus. None of these strains were agglutinated by the antisera to the surface proteins of $V$. cholerae suggesting that the surface proteins of $V$. cholerae are antigenically dissimilar to those of other pathogenic members of the genus Vibrio (Table 2). Further, the antisera did not agglutinate any strain from other diarrhoea causing bacteria such as enterotoxigenic E. coli, S. typhi, A. hydrophila, Shigella spp. and $Y$. enterocolitica. 


\section{DISCUSSION}

Serological and antigenic properties of cell surface proteins of $V$. cholerae have been studied with proteins extracted by treatment with EDTA/ $\mathrm{NaCl}$. The following evidence suggests this method of extraction is specific. Firstly, by applying the radioimmunochemical technique involving the binding of ${ }^{125} \mathrm{I}$-protein $\mathrm{A}$ to cell-bound immunoglobulins, it has been demonstrated in this investigation that the EDTA extracted proteins were localized on the bacterial surface. Secondly, with the ELISA test high titres of protein specific antibodies were detected in the immune rabbit sera, raised against whole bacteria. This suggests that these protein moieties, which were immunogenic, were exposed on the cell surface. Thirdly, antisera to the EDTA-extracted proteins agglutinated several strains of $V$. cholerae belonging to both biotypes and serotypes. Absorption of the antisera with living $V$. cholerae completely removed agglutinating antibodies. Finally, extracted proteins had polypeptides similar to those of the outer membrane of $V$. cholerae isolated from the cell envelope by Triton X-100 (Kabir, 1980). Although the present method produced a few more polypeptides a major component in both the preparations had a molecular weight of 48000 . Recently, Geyer et al. (1979) have used EDTA $/ \mathrm{NaCl}$ to isolate cell surface proteins from Gram-negative bacteria such as Salmonella minnesota.

There are several polypeptides shared by $V$. cholerae strains irrespective of the biotypes and serotypes. This was confirmed by PAGE which showed the presence of polypeptides of similar molecular weights. Vibrio cholerae is known to possess flagellar antigens which are shared by other members of the Vibrio family (Bhattacharyya, 1977). Hence antibodies to the flagellar antigens cannot differentiate $V$. cholerae from other pathogenic vibrios for man, such as non-O1 $V$. cholerae and $V$. parahaemolyticus. But as observed in this investigation, antisera to the surface protein antigens of $V$. cholerae are specific and hence, can be used for rapid screening of cholera vibrios from other diarrhoeagenic bacteria. At present, the serological identification of $V$. cholerae is done by the agglutination test with the polyvalent antiserum raised to both Ogawa and Inaba strains. Since serotype specificities are of little significance in clinical cholera, agglutination tests against the antisera to the surface proteins of $V$. cholerae should prove to be a quick diagnostic procedure for the identification of $V$. cholerae.

From the present investigation it appears that the surface proteins were immunogenic as high titre protein specific antibodies were detected in the immune sera. Previous investigations have shown that the surface proteins of $V$. cholerae did not possess toxic properties (Kabir \& Mann, 1980). Therefore, these proteins can be explored as a potential non-toxic vaccine candidate against cholera.

The helpful advice offered by Dr B. Withot and Ms G. H. Vos-Scheperkeuter in the radioiodination experiment is gratefully acknowledged. I thank Ms Ingrid Kabir for her financial support during the preparation of the manuscript.

\section{REFERENCES}

BHATTACHARYYA, F. K. (1977). The agglutination reaction of cholera vibrios. Japan Journal of Medical Science and Biology 30, 259-268.

Craig, J. P. (1980). A survey of the enterotoxic enteropathies. In Cholera and Related Diarrheas, pp. 15-25. Edited by Ö. Ouchterlony \& J. Holmgren. Basel: Krager.

Crumpton, M. J. \& Wilkinson, J. M. (1963). Amino acid compositions of human and rabbit $\gamma$-globulins and of the fragments produced by reduction. Biochemical Journal 88, 228-234.

FIELD, M. (1971). Intestinal secretion: effect of cyclic AMP and its role in cholera. New England Journal of Medicine 284, 1137-1144.

Geyer, R., Galanos, C., Westrhal, O. \& LÜDERItz, O. (1979). A lipopolysaccharide-binding cell surface protein from Salmonella minnesota. European Journal of Biochemistry 98, 27-38.

Hunter, W. M. \& Greenwood, F. C. (1962). Preparation of iodine-131 labelled human growth hormone of high specific activity. Nature, London 194, 495-496.

KABIR, S. (1980). Composition and immunochemical properties of the outer membrane proteins of Vibrio cholerae. Journal of Bacteriology 144, 382-389.

KABIR, S. \& MANN, P. (1980). Immunological properties of the cell envelope components of Vibrio cholerae. Journal of General Microbiology 119, 517525.

KInG, J. \& Laemmli, U. K. (1971). Polypeptides of the tail fibres of bacteriophage T4. Journal of Molecular Biology 62, 465-477. 
Langone, J. J., Boyle, D. P. M. \& Borsos, T. (1977). ${ }^{125}$ I-Protein A: applications to the quantitative determination of fluid phase and cell-bound IgG. Journal of Immunological Methods 18, 281293.

Levine, M. M., Nalin, D. R., Craig, J. P., Hoover, D., Bergquist, E. J., Waterman, D., Holley, H. P., Hornick, R. B., Pierce, N. F. \& Libonati, J. P. (1979). Immunity to cholera in man: relative role of antibacterial versus antitoxic immunity. Transactions of the Royal Society of Tropical Medicine and Hygiene 73, 3-9.

Majumdar, A. S., Dutta, P., Dutta, D. \& Ghose,
A. C. (1981). Antibacterial and antitoxin responses in the serum and milk of cholera patients. Infection and Immunity 32, 1-8.

Sjoquist, J., Meloun, B. \& Helm, H. (1972). Protein A isolated from Staphylococcus aureus after digestion with lysostaphin. European Journal of Biochemistry 29, 572-578.

WestPhal, O. \& JANN, K. (1965). Bacterial lipopolysaccharides. Methods in Carbohydrate Chemistry 5 , 83-96.

WESTPHAL, O., LÜDERITZ, O. \& BisTER, F. (1952). Über die Extraktion von Bakterien mit Phenol-wasser, Zeitschrift für Naturforschung B7, 148-155. 